\title{
Effect of Advanced Rice Production Technologies on Household Economic Development in Kilombero Valley, Tanzania
}

\author{
Lawi S. Mhoja, Harrieth G. Mtae, PhD* and Cosmas Haule \\ The Open University of Tanzania \\ *Corresponding Mail: $\underline{\text { harrieth.mtae@out.ac.tz }}$
}

\begin{abstract}
This study examined the effect of advanced rice production technologies on household economic development among smallholder farmers in Kilombero valley, Tanzania in terms of farmers' ability to get three meals per day, ability to educate children and ability to own assets like a TV. The study employed the causal-effect survey design. A total of 100 smallholder rice farmers from four wards were sampled through simple random sampling. Twenty smallholder farmers among the 100 sampled farmers who previously received certificates of appreciation as successful users of advanced rice technologies were sampled through purposive sampling as key informants. Data were collected using questionnaire which aimed to capture effect of utilization of new rice production technologies on household economic development among farmers (adopters). Spearman's rho Correlation coefficienttest was used to analyse data and test the hypotheses. The study concludes that utilization of advanced rice production technologies positively affected the household economic development in that, as farmers utilized improved rice seeds, site-specific-nutrient technology, direct-seeded-rice technology and pests and diseases technologies, their quality of life improved. It is therefore recommended that site-specific-nutrient technology, direct-seeded-rice technology and pests and diseases technology need to be considered by farmers for improved outcomes.
\end{abstract}

Keywords: Advanced rice production technologies, utilization, household economic development, smallholder farmers, Tanzania

\section{Introduction}

Advanced rice technologies are ones that increase rice yields (Rehman, et al. 2016). Advanced rice technologies include all kinds of improved techniques and practices which affect the growth of rice output (Jaine, Arora \& Raju, 2009). Advanced rice technologies are seen as an important way out of poverty in most of the developing countries because they help in increasing rice yields and income (Margaret \& Samuel 2015). Unfortunately, the majority of smallholder farmers rely on traditional methods of production and this has lowered their level of productivity. For instance, over $70 \%$ of maize production in most of developing countries is from smallholder farmers who use traditional methods of production. These farmers generally obtain very low crop yields because the local varieties used have low potential yields. Most of the maize is grown under rain-fed conditions and irrigation is used on limited cases; little or no fertilizers are used and pest control is not adequate (Muzari, Gatsi, \& Muvhunzi 2012).

Loevinsohn, Sumberg and Diagne (2012) define adoption as the integration of a new technology into the existing practice and is usually proceeded by a period of 'trying' and some degree of adaptation. For Rogers (2003), adoption is a decision of "full use of an innovation as the best course of action available" and rejection is a decision "not to adopt an innovation." Agriculture is the engine of economic growth, development and improved livelihood in African countries including Tanzania (Nyagahima, 2010). Despite the essentials of agriculture in economic development and various agriculture initiatives by the government of Tanzania, the sector has remained poor due to unproductive systems of agriculture practices which includes low productivity of land, limited labor and production inputs, underdeveloped irrigation, 
limited capital, limited access to financial services, inadequate agricultural technical support services, poor rural infrastructure, infestations and outbreaks of crop pests and diseases, erosion of natural resource base and environmental degradation (Mtega and Msungu, 2013).

About two-thirds of the developing world's 3 billion rural people live in 475 million small farm households, working on land plots smaller than 2 hectares (George, 2015). Many small farmers are poor with food insecurities as well as limited access to markets and services. Their choices are constrained but they farm their land and produce food for substantial proportion of the world's population. Besides farming, they have multiple economic activities often in the informal economy to contribute towards their small incomes. These farmers depend predominantly on family labour. In China, nearly $98 \%$ of farmers cultivate farms smaller than 2 hectares, and the country alone accounts for almost half the world's small farms. In India about $80 \%$ of farmers are small. In Ethiopia and Egypt farms smaller than 2 hectares constitute nearly $90 \%$ of the total number of farms. In Mexico, $50 \%$ of farmers are small; in Brazil, smallholders make up for $20 \%$ of the total number of farmers (George, 2015).

In Tanzania, the level of farm mechanization is still low in that majority (97.8\%) of the implements found on farming households on mainland use hand hoes and $93.5 \%$ use swords. Relatively, a small number of households use other farming implements such as ox plough (14.4\%), castrated bulls (13.7\%), hand sprayers (11.7\%) and cows (10.2\%). Other farm machinery (tractors, power tillers) are nearly $1 \%$ (United Republic of Tanzania, 2015/2016-2024/2025). In Tanzania, 35.7\% of the population lives below the basic needs' poverty line and $18.7 \%$ live below the food poverty line. Women in Tanzania are subject to live in extreme poverty compared to men and this is due to the fact that women lack concerns in development programs/projects and are voiceless in many aspects of development (Khaliq, Naeem, Abbas and Khalid, 2016).

In some of the areas in Tanzania mainland, including Kilombero Valley in Morogoro Region, there were some improvements in living conditions. The households saw large improvements between 2007 and 2011/2012 in their housing conditions through modern amenities such as television sets and mobile phones. Ownership of agricultural land improved as well, but possession of productive assets such as mechanized equipment and big livestock is still limited. While these improvements were experienced mainly by less well-off households, members of those households continued to suffer from different forms of deprivations. More than half of the poor and rural dwellers still live-in pitiable housing conditions and lack important assets. Access to basic infrastructure (electricity, piped water) also remains limited (World Bank Group, 2012). Therefore, this study endeavored to establish the effect of utilization of advanced rice production technologies on household economic development among adopters in Kilombero Valley, in order to help smallholder farmers improve quality of life. The study was guided by the following specific objectives which were later turned into hypotheses:

1. To assess effect of utilization of improved rice seeds on household economic development among farmers (adopters).

2. To assess effect of utilization of site-specificnutrient technology on household economic development among adopters.

3. To assess effect of direct-seeded rice technology on household economic development among adopters.

4. To assess effect of pests and diseases control technology on household economic development among adopters.

\section{Literature Review}

This section presents literature review on related studies regarding the effect of advanced rice production technologies on household economic development among smallholder farmers. Literature review focused on improved rice seeds technology, site-specific-nutrient technology, direct-seeded-rice technology and pests and diseases control technology variables.

\section{Improved Rice Seeds}

The Ministry of Agriculture, Food and Security Cooperations (2009) conducted a study in Tanzania mainland and found that there are hundreds of local/traditional rice varieties grown by farmers in the rain-fed lowland, irrigated lowland and upland ecosystems. Most of these varieties have low yield potential, late maturing and are prone to lodging when improved management practices such as application of fertilizers are used. Improved seeds have been applied by only 10 percent of farmers. The use of self-saving seeds is common among small-scale rice farmers and these seeds are of low quality. Food and Agriculture Organization's (2015) 
findings revealed that overall, the rice technology in use in Tanzania is old. The sore exception is the variety TXD 306 commonly known as 'Saro 5' ('saro = semi - aromatic rice). This is a high -yielding cultivar developed by the Ifakara Research Centre (formerly the Kilombero Agricultural Research and Training Institute and the Regional Rice Centre of Excellence which is responsible for rice technology improvement and transfer.

\section{Site-Specific Nutrient Technology}

Site-specific-nutrient technology includes dynamic adjustments in fertilizer management to accommodate field and season specific conditions, effective use of indigenous nutrients, efficient fertilizer (N) management through the use of the Leaf Color Chart (LCC) and the use of the omission plot technique to determine the requirements for $P$ and $K$ deficiencies and avoid mining of these nutrients from the soil (Pampolino et al., 2007).

Rodriquez and Nga (2012) conducted a study in Philippines to examine paddy productivity in terms of yields and income as the outcome of adopting Site-Specing Nutrient Management (SSNM) technology. The study found that SSNM improved paddy yield by 0.6 tones per hectare (ha) and increased profit by USD 150 per ha. The evidence on the impact of SSNM is limited and the need for more rigorous evaluation studies is high.

\section{Direct Seeded Rice Technology}

The dominant method of rice establishment is transplanted from Asian countries. However, labor costs for establishing a nursery, preparing fields and transplanting have increased significantly and are expected to further increase in future. Directseeding of rice (DSR) is a method of establishing a rice crop by sowing seeds directly in the field without shifting the seeds from the nursery to the field which is very cheap than transplanting (Falooq et al., 2011).

Using the comprehensive data set collected from 238 rice producers during the year 2011, Ali, Erenstein and Rahut (2014) conducted a study to find out the impact of direct seeding of rice sowing technology on rice crop yields and farmers' earnings in Pakistan. The results indicated that the adopters of the direct rice sowing technology had higher rice yields as compared to non-adopters. Results further showed that the adopter households had a higher income compared to non-adopter households. Most importantly, the technology is water-saving and on average requires four times less irrigation than the traditional rice transplanting method. With the direct rice-sowing technology, the demand for skilled labor was less compared to the traditional transplanting method. However, the new technology is associated with weed control problems which need to be addressed in order to maximize the benefits from the new technology.

\section{Pests and Diseases Management Technology}

The introduction of modern agricultural technologies in 1960s and 1970s dramatically increased the use of chemical inputs including pesticide without adequate knowledge about health and environmental side effects. Integrated Pest Management (IPM) was developed and promoted in the major rice-producing regions in Southeast Asia. In the Mekong Delta of Vietnam, a media campaign was started in 1994 to motivate farmers to reduce pesticide spraying in the first 40 days after sowing. This campaign was based on earlier finding that early spraying was unnecessary as any damage from leaf-feeding insects seldom affected yields (Yamano, Labarta, Arauna \& Huelgas, 2016).

Huan, Thiet, Chien \& Heong (2005) conducted a farmer participatory study with 951 farmers and observed little differences in rice yields between rice experimental plots (with reduced pesticide sprays, seed rates and nitrogen fertilizer) and control plots. Because of the reduced input costs, the authors found higher income on the experimental plots.

Huelgas and Templeton (2010) studied the impact of usage of pests and diseases technology in Nigeria through a survey in 2005 and reported farm-level income benefits through reduced costs (Yamano et al., 2016). By using panel data from Indonesia, Yamazak and Resosudarmo (2008) examined the impact of the use of pests and management technology on quality of life and found immediate positive impacts of IPM-FFS programs in short-run impacts (Yamano, Labarta, Arauna \& Huelgas, 2016).

Previous studies examined the effect of adoption of new rice technologies on quality of life by comparing two different groups of smallholder rice farmers (adopters and non-adopters). However, the studies did not examine effect of utilization of advanced rice production technologies on household economic development among adopters only. Hence, this study filled the gap by assessing the effect of utilization of advanced rice production 
technologies on household economic development among adopters only.

\section{Research Methodology}

This section presents the research methodology used to guide this study.

\section{Research Design}

Research design as described by Goddad and Melvile (2004) refers to an overall strategy that a researcher chooses to integrate the different components of the study in a coherent and logical way to ensure that the problem is sufficiently and effectively addressed. This study used the causaleffect survey design to examine the effect of utilizing the advanced rice technologies on household economic development among smallholder farmers from Kilombero valley. This type of research is used to measure what impact a specific change will have on an existing norms and assumptions (Akhtar, 2016). Causal effect occurs when variation in one phenomenon (independent variable) leads in variations in another phenomenon (dependent variable) (ibid).

\section{Population and Sampling}

The study was conducted in four villages from three districts of Kilombero, Ulanga and Malinyi in Morogoro Region: Mofu village and Namawala Village from Kilombero District, Rupilo Village from Ulanga District and Mtimbila Village from Malinyi District. The majority of the households living in Kilombero, Ulanga and Malinyi Districts were generally poor farmers and fishermen, highly depending on crop cultivation, livestock rearing, fishing and hunting (Mombo, 2017, P. 5). Since most people especially small-scale farmers depend on agriculture to support their living, agriculture is the main activity practiced in Kilombero, Ulanga and Malinyi Districts. In Kilombero and Ulanga Districts, both rain fed and irrigated agriculture are practiced (Mombo, 2017).

\section{Data Collection Instruments}

In this study, 100 questionnaires were distributed to smallholder farmers who adopted advanced rice technologies in Kilombero valley. Additionally, twenty famers who previously were given by the government certificates of appreciation as successful users of advanced rice technologies were picked from 100 farmers as key informants.

\section{Validity of the study}

Validity involves assessing the measurement techniques and assessing what they intend to measure (Drost, 2012, P. 114). To ensure the validity, two experts were given the instruments against the research questions to check and give comments for improvement so that the instruments would be able to measure what was intended.

Reliability is defined as the degree to which measures are free from error and yields consistent results (Ellis and Levy, 2009, P. 333). In order to ensure that the tools were reliable, the researchers used Cronbach's Alpha to test the reliability of quantitative concepts (data).The results yielded the Cronbach's Alpha of above 0.7 which indicates that the questionnaire was reliable. Furthermore, triangulation, the use of multiple instruments, questionnaire and interview schedule enhanced the reliability of the study.

\section{Statistical Treatment of Data}

In this study, Spearman's correlation coefficient rhotest was applied in data analysis to establish the relationship among the variables under investigation through appropriate tables.

\section{Ethical Considerations}

Before conducting the study, researchers asked permission from government officials to conduct the study. The researchers further ensured confidentiality of data, anonymity and freedom of respondents to participate.

\section{Results and Discussions}

This section presents results and discussions based on the objectives that guided this study:

Objective 1: To assess effect of utilizing improved rice seeds on household economic development among farmers (adopters).

In order to assess effect of utilizing advanced rice production technologies on household economic development among smallholder rice farmers in Kilombero Valley, the study tested the following null hypothesis: There is no significant relationship between utilizing improved rice seeds and household economic development among farmers (adopters).

Due to the Sig of .000 in table 2, (p. 226) which is lesser than the critical value, findings reveal a significant positive effect of utilizing improved rice seeds on household economic development in terms of ability to get three meals per day (.432), ability to educate children (.369), and ability to own an asset like a TV) (.510) at the 0.01 level of significance for Spearman's rho test. This implies 
that utilization of improved rice seeds has a positive effect on household economic development among adopters. Therefore, the null hypothesis is rejected. The findings agree with those by Asfaw, Kassie, Simtowe and Lipper (2012) in a study conducted in Ethiopia who found out that adoption of improved seed varieties had a significant positive impact on farmers' welfare. Furthermore, this result is supplemented by a young key informant (female, 28 years) from Namwawala village, who said that "I have three acres which I normally use for farming and due to scarcity of fund sometimes in two acres I use traditional rice seeds and the other acre I use improved rice seeds. The one acre gives me more produces (28-35 sacks per acre) while the other two acres give me lesser produces (7-8 sacks per acre)." In support of this finding, another informant (male, 38 years) from Namwawala village recommended that, "the government of Tanzania should conduct national agricultural shows not only on zonal basis in cities and towns but they should also conduct national agricultural shows in villages so that the majority of farmers may access easily agricultural information to motivate them to use improved rice seeds in order to improve quality of life and household economic development."

Objective 2: To assess effect of site-specific nutrient technologies on household economic development among farmers (adopters).

Table 1: Effect of Utilizing Improved Rice Seeds on Household Economic Development

\begin{tabular}{|c|c|c|c|c|c|}
\hline & & $\begin{array}{c}\text { Adopt } \\
\text { Improved } \\
\text { Rice Seeds }\end{array}$ & $\begin{array}{c}\text { Able to get } \\
\text { Three Meals } \\
\text { per Day }\end{array}$ & $\begin{array}{l}\text { Able to } \\
\text { Educate } \\
\text { Children }\end{array}$ & $\begin{array}{c}\text { Able to Own } \\
\text { an Asset like a } \\
\text { TV }\end{array}$ \\
\hline \multirow{3}{*}{$\begin{array}{l}\text { Adopt Improved } \\
\text { Rice Seeds }\end{array}$} & Correlation Coefficient & 1.000 & $.432^{* *}$ & $.369^{* *}$ & $.510^{* *}$ \\
\hline & Sig. (2-tailed) & & .000 & .000 & .000 \\
\hline & $\mathrm{N}$ & 99 & 99 & 99 & 99 \\
\hline \multirow{3}{*}{$\begin{array}{l}\text { Able to get Three } \\
\text { Meals per Day }\end{array}$} & Correlation Coefficient & $.432^{* *}$ & 1.000 & $.699^{* *}$ & $.673^{* *}$ \\
\hline & Sig. (2-tailed) & .000 & & .000 & .000 \\
\hline & $\mathrm{N}$ & 99 & 99 & 99 & 99 \\
\hline \multirow{3}{*}{$\begin{array}{l}\text { Able to Educate } \\
\text { Children }\end{array}$} & Correlation Coefficient & $.369^{* *}$ & $.699^{* *}$ & 1.000 & $.731^{* *}$ \\
\hline & Sig. (2-tailed) & .000 & .000 & & .000 \\
\hline & $\mathrm{N}$ & 99 & 99 & 99 & 99 \\
\hline \multirow{3}{*}{$\begin{array}{l}\text { Able to Own an } \\
\text { Asset like a TV }\end{array}$} & Correlation Coefficient & $.510^{* *}$ & $.673^{* *}$ & $.731^{* *}$ & 1.000 \\
\hline & Sig. (2-tailed) & .000 & .000 & .000 & \\
\hline & $\mathrm{N}$ & 99 & 99 & 99 & 99 \\
\hline
\end{tabular}

Table 2: Effect of site-specific nutrient technologies on Household Economic Development

\begin{tabular}{|c|c|c|c|c|c|}
\hline & & $\begin{array}{l}\text { Adopt Site- } \\
\text { Specific-Nutrient } \\
\text { Technology }\end{array}$ & $\begin{array}{l}\text { Able to get } \\
\text { Three Meals } \\
\text { per Day }\end{array}$ & $\begin{array}{l}\text { Able to } \\
\text { Educate } \\
\text { Children }\end{array}$ & $\begin{array}{l}\text { Able to Own } \\
\text { an Asset like } \\
\text { a TV }\end{array}$ \\
\hline Adopt Site-Specific- & Correlation Coefficient & 1.000 & $.275^{* *}$ & $.319^{* *}$ & $.429^{* *}$ \\
\hline Nutrient & Sig. (2-tailed) & & .006 & .001 & .000 \\
\hline Technology & $\mathrm{N}$ & 99 & 99 & 99 & 99 \\
\hline Able to get Three & Correlation Coefficient & $.275^{* *}$ & 1.000 & $.699^{* *}$ & $.673^{* *}$ \\
\hline \multirow[t]{2}{*}{ Meals per Day } & Sig. (2-tailed) & .006 & & .000 & .000 \\
\hline & $\mathrm{N}$ & 99 & 99 & 99 & 99 \\
\hline Able to Educate & Correlation Coefficient & $.319^{* *}$ & $.699^{* *}$ & 1.000 & $.731^{* *}$ \\
\hline \multirow[t]{2}{*}{ Children } & Sig. (2-tailed) & .001 & .000 & & .000 \\
\hline & $\mathrm{N}$ & 99 & 99 & 99 & 99 \\
\hline Able to Own an & Correlation Coefficient & $.429^{* *}$ & $.673^{* *}$ & $.731^{* *}$ & 1.000 \\
\hline \multirow[t]{2}{*}{ Asset like a TV } & Sig. (2-tailed) & .000 & .000 & .000 & \\
\hline & $\mathrm{N}$ & 99 & 99 & 99 & 99 \\
\hline
\end{tabular}

**. Correlation is significant at the 0.01 level (2-tailed).

In order to assess effect of site-specific nutrient technologies on household economic development among smallholder rice farmers in Kilombero Valley, the study tested the following null hypothesis: There is no significant relationship between site-specific nutrient technologies and household economic 
development among farmers (adopters) as indicated in table 2:

Due to the Sig of $.006, .001$ and .000 in table 2, which is lesser than the critical value, findings reveal a significant positive effect of site-specific nutrient technologies on household economic development in terms of ability to get three meals per day (.275), ability to educate children (.319), and ability to own an asset like a TV) (.429) at the 0.01level of significance for Spearman's rho test. This implies that site-specific nutrient technologies have a positive effect on household economic development among adopters. Therefore, the null hypothesis is rejected. This finding is similar to that by LiverpoolTasie (2017) in Nigeria who found that inorganic fertilizer uses in particular and other agricultural technologies in general are profitable. Furthermore, this finding is supplemented by information from one of the key informants (male, 40 years) from Mofu village, who said that "site-specific-nutrient technologies help me to get enough food for home use and for trade."

Objective 3: To assess effect of direct seeded rice technologies on household economic development among farmers (adopters).

In order to assess effect of direct seeded rice technologies on household economic development among smallholder rice farmers in Kilombero Valley, the study tested the following null hypothesis as indicated in table 3: There is no significant relationship between direct seeded rice technologies and household economic development among farmers (adopters).

Table 3: Effect of direct seeded rice technologies on Household Economic Development

\begin{tabular}{|c|c|c|c|c|c|}
\hline & & $\begin{array}{l}\text { Adopt Direct- } \\
\text { Seeded-Rice } \\
\text { Technology }\end{array}$ & $\begin{array}{c}\text { Able to get } \\
\text { Three Meals } \\
\text { per Day }\end{array}$ & $\begin{array}{l}\text { Able to } \\
\text { Educate } \\
\text { Children }\end{array}$ & $\begin{array}{c}\text { Able to Own } \\
\text { an Asset like a } \\
\text { TV }\end{array}$ \\
\hline Adopt Direct- & Correlation Coefficient & 1.000 & $.285^{* *}$ & $.274^{* *}$ & $.440^{* *}$ \\
\hline Seeded-Rice & Sig. (2-tailed) & & .004 & .006 & .000 \\
\hline Technology & $\mathrm{N}$ & 99 & 99 & 99 & 99 \\
\hline Able to get Three & Correlation Coefficient & $.285^{* *}$ & 1.000 & $.699^{* *}$ & $.673^{* *}$ \\
\hline \multirow[t]{2}{*}{ Meals per Day } & Sig. (2-tailed) & .004 & & .000 & .000 \\
\hline & $\mathrm{N}$ & 99 & 99 & 99 & 99 \\
\hline Able to Educate & Correlation Coefficient & $.274^{* *}$ & $.699^{* *}$ & 1.000 & $.731^{* *}$ \\
\hline \multirow[t]{2}{*}{ Children } & Sig. (2-tailed) & .006 & .000 & & .000 \\
\hline & $\mathrm{N}$ & 99 & 99 & 99 & 99 \\
\hline Able to Own an & Correlation Coefficient & $.440^{* *}$ & $.673^{* *}$ & $.731^{* *}$ & 1.000 \\
\hline \multirow[t]{2}{*}{ Asset like a TV } & Sig. (2-tailed) & .000 & .000 & .000 & \\
\hline & $\mathrm{N}$ & 99 & 99 & 99 & 99 \\
\hline
\end{tabular}

**. Correlation is significant at the 0.01 level (2-tailed).

In order to assess effect of direct seeded rice technologies on household economic development among smallholder rice farmers in Kilombero Valley, the study tested the following null hypothesis: There is no significant relationship between direct seeded rice technologies and household economic development among farmers (adopters) and the findings are presented in table 4.

Due to the Sig of .004, .006 and .000 in table 4, which is lesser than the critical value, findings reveal a significant positive effect of direct seeded rice technologies on household economic development in terms of ability to get three meals per day (.285), ability to educate children (.274), and ability to own an asset like a TV) (.440) at the 0.01level of significance for Spearman's rho test. This implies that direct seeded rice technologies have a positive effect on household economic development among adopters. Therefore, the null hypothesis is rejected. This finding is in harmony with that by Malabayabas, Templeton and Singh (2012) in India who surveyed 40 farmers with both DSR and transplanting. Results indicated that average net income was higher for DSR than for transplanting, mainly because of the lower labor costs for DSR. Furthermore, this result is supplemented by information from key informant (female, 56 years) from Mtimbila village, who said that "I have been avoiding direct seeded rice technology because of its complications though she agreed to observe some of the old (aged) farmers who try the technology to succeed in terms of yields and economic development."

Objective 4: To assess effect of pests and diseases management technologies on household economic development among farmers (adopters). 
In order to assess effect of pests and diseases management technologies on household economic development among smallholder rice farmers in Kilombero Valley, the study tested the following null hypothesis: There is no significant relationship between pests and diseases management technologies and household economic development among farmers (adopters) as indicated in table 4.

Table 4: Effect of pests and diseases management technologies on Household Economic Development

\begin{tabular}{|c|c|c|c|c|c|}
\hline & & $\begin{array}{l}\text { Pest } \\
\text { Management } \\
\text { Technology }\end{array}$ & $\begin{array}{l}\text { Able to get } \\
\text { Three Meals } \\
\text { per Day }\end{array}$ & $\begin{array}{l}\text { Able to } \\
\text { Educate } \\
\text { Children }\end{array}$ & $\begin{array}{l}\text { Able to Own } \\
\text { an Asset like } \\
\text { a TV }\end{array}$ \\
\hline Pest Management & Correlation Coefficient & 1.000 & $.263^{* *}$ & $.342^{* *}$ & $.413^{* *}$ \\
\hline \multirow[t]{2}{*}{ Technology } & Sig. (2-tailed) & & .009 & .001 & .000 \\
\hline & $\mathrm{N}$ & 99 & 99 & 99 & 99 \\
\hline Able to get Three & Correlation Coefficient & $.263^{* *}$ & 1.000 & $.699^{* *}$ & $.673^{* *}$ \\
\hline \multirow[t]{2}{*}{ Meals per Day } & Sig. (2-tailed) & .009 & & .000 & .000 \\
\hline & $\mathrm{N}$ & 99 & 99 & 99 & 99 \\
\hline Able to Educate & Correlation Coefficient & $.342^{* *}$ & $.699^{* *}$ & 1.000 & $.731^{* *}$ \\
\hline \multirow[t]{2}{*}{ Children } & Sig. (2-tailed) & .001 & .000 & & .000 \\
\hline & $\mathrm{N}$ & 99 & 99 & 99 & 99 \\
\hline Able to Own an & Correlation Coefficient & $.413^{* *}$ & $.673^{* *}$ & $.731^{* *}$ & 1.000 \\
\hline \multirow[t]{2}{*}{ Asset like a TV } & Sig. (2-tailed) & .000 & .000 & .000 & \\
\hline & $\mathrm{N}$ & 99 & 99 & 99 & 99 \\
\hline
\end{tabular}

**. Correlation is significant at the 0.01 level (2-tailed).

Due to the Sig of .009, .001 and .000 in table 5, which is lesser than the critical value, findings reveal a significant positive effect pests and diseases management technologies on household economic development in terms of ability to get three meals per day (.263), ability to educate children (.342), and ability to own an asset like a TV) (.413) at the 0.01level of significance for Spearman's rho test. This implies pests and diseases management technologies have a positive effect on household economic development among adopters. Therefore, the null hypothesis is rejected. The result is supplemented by one of the key informant (female, 64 years) from Rupilo insisted that, "Farmers who adopt pests and diseases management technology achieve high yields and economic development."

\section{Conclusions and Recommendations}

This section presents the conclusions of the study and then follow the recommendations thereof.

\section{Conclusions}

The study concludes that utilization of advanced rice production technologies positively affects the household economic development in that, as farmers utilize improved rice seeds, site-specificnutrient technology, direct-seeded-rice technology and pests and diseases technologies, their quality of life will be improved.

\section{Recommendation}

Based on the conclusions above, it is therefore recommended that improved rice seeds technology, site-specific-nutrient technology, direct-seeded-rice technology and pests and diseases technology need to be considered by farmers under investigation for improved outcomes.

\section{Reference}

Akhtar, I. (2016). Research Design. Retrieved from: https://www.researchgate.net/ public atio n/30891554 8-Research-Design. Accessed April 9, 2020.

Ali, A., Erenstein, O. \& Rahut, B.D. (2014). Impact of direct rice sowing technology on rice producers' earnings: empirical evidence from Pakistan. Development Studies Research, An Open Access Journal. Vol. 1(1). Retrieved from: https://www.t andf onli ne.com/ doi/full/10.1080 /21665095 .201 4.943777.

Asfaw, S., Kassie, M., Simtowe, F. \& Lipper, L. (2012). Poverty Reduction Effects of Agricultural Technology: A Micro-evidence from Rural Tanzania. Journal of Development Studies, Vol.7(3). Accessed October 28, 2018 at https://www.researchgate.net/... $/ 254 \quad 24$ 2851 -poverty-Reduction-Effects-ofAgricultural... 
Drost, E. A (2012). Validity and Reliability in Social Science Research. Education Research and Perspectives 38(1), 114.

Ellis, T.J. \& Levy, Y. (2009). Towards a Guide for Novice Researchers on Research Methodology: Review and proposed methods. Issues in Informing Science and Information Technology, 6, 333.

Falooq, M., Siddique, K.H.M., Rehman, H., Aziz, T., Lee. D.J., Wahid, A (2011). Rice direct seeding: experiences, challenges, opportunities, Soil Tillage Res. 111(2).

Food and Agriculture Organization (2015). The economic lives of smallholder farmers. FAO, Rome. Retrieved from: https://www.fao.org. Accessed on September 14, 2020.

George, R. (2015). The economic lives of smallholder farmers: An analysis based on household data from nine countries, Food and Agriculture Organization of the United Nations (FAO), Rome. Retrieved from: Accessed October 18, 2018.

Goddad, W. \& Meville, S. (2004). Research Methodology: An introduction, Juta and Company, Lansdowne.

Huan, N.H., Thiet, L.V., Chien, H. V., Heong, K.L (2005). Farmers' participatory evaluation of reducing pesticides, fertilizers and seed rates in rice farming in the Mekong Delta Vietnam Crop Prot. 24.

Huelgas, Z.M., Templeton, D.J (2010). Adoption of Crop Management Technology and costefficiency impacts: the case of three reductions, three gains in the Mekong River Delta of Vietnam. In: Palis, F.G., Singleton, G.R., Casimero, M.C., Hardy, B. (Eds). Research to impact: Case studies for Natural Resource Management for irrigated Rice in Asia. International Rice Research Institute, Los Baflos (Philippines).

Jaine, R, Arora, A. \& Raju, S. (2009). A Novel Adoption Index of Selected Agricultural Technologies: Linkages with Infrastructure and productivity: Agricultural Economics Research Revie, Vol. 22. Retrieved from: https://ageconsearch.umn.edu/files/9-Rajn i-PDF.
Khaliq, I.H., Naeem, B., Abbas, Q., Khalid, S. (2016). Contribution of IC to poverty Reduction among women in Kilosa District. J Bus Fin Aff6: 238.doi: 10.4172/2167-0234.1000238.

Liverpool-Tasie, L.S.O. (2017). Is Increasing Inorganic Fertilizer Use for Maize Production in SSA a Profitable Proportion? Evidence from Nigeria. Food Policy. Retrieved from http://dx.doi.org/10.1016/j.Foodpol.

Loevinsohn, M., Sumberg, J. \& Diagne, A. (2012). Under what circumstances and conditions does adoption of technology result in increased agricultural productivity? Protocol. London: EPPI Centre, Social Science Research Unit, Institute of Education, University of London.

Malabayabas, A.J., Templeton, D., Singh, P (2012). Ex-ante impact of direct seeding of rice as an alternative to transplanting rice in the indo-Gangetic plain. Asian J. Agric. Dev. 9(2).

Margaret, M. \& Samuel, K. (2015). Factors Determining Adoption of New Agricultural Technology by Smallholder Farmers in Developing Countries. Journal of Economics and Sustainable Development, Vol. 6. No 5.

Ministry of Agriculture and Food Security Cooperation (2009). National Rice Development Strategy Final Draft. Retrieved from: https://www.jica.g o.jp/agriculture al/pdf/tanzania-en/PDF.

Mombo, F. (2017). Conservation and Livelihoods: Where do we strike a balance to sustain the Wetlands in Kilombero valley? Research Journali's Journal of Agriculture. Vol. 4/No. 7/2017. Retrieved from: https://www.su aire.suanet.ac.tz:8080/xmlui/.../Felister\%20 Mombo\%2015\%20paper.pdf.

Mtega, W.P \& Msungu, A.C. (2013). Using Information and communication Technologies for enhancing the Accessibility of Agricultural Information for Improved Agricultural Production in Tanzania, The electronic Journal of Information systems in the Developing countries 50(1). Retrieved from: http://www.eijsdc.org.

Muzari, W. Gatsi, W. \& Muvhunzi, S. (2012). The Impacts of Technology Adoption on Smallholder Agricultural Productivity in Subsaharan Africa: A review, Journal of Sustainable Development; Vol. 5(8). 
Nyagahima, J. (2010). ICT Capacity for Agricultural Research and Development Conference on Higher Education in Agriculture in Africa. Retrieved from: http://www.ruforum.org/ sites/default/files/file/CHEA/Presentatio ns/0 12.pdf.

Pampolino, M.F., Manguiat, I.J. Ramanathan, S., Gines, H.C., Tan, P.S., Chi T.T.N., Rejendran, R., Buresh, R.J (2007). Environmental benefits of site-specific nutrient management (SSNM) in irrigated rice systems. Agric. Syst. 93.

Rehman, A., Jingdong, L., Khatoon, R., Iqbal, M.S. \& Hussain, I. (2016). Effect of Agricultural Growth on Poverty Reduction, its Importance and Suggestions. Transy/vanian Review: Vol. 25. No 5. Special Issue. Retrieved from https://www.researchgate .net/.../309209587-Effect-of-AgriculturalGrowth-on-poverty.

Rogers, E.M. (2003). Diffusion of Innovations $\left(5^{\text {th }}\right.$ ed.). New York: The Free Press.

Rodriquez, D.G.P., Nga, N.T.D (2012). Impacts of site-specific nutrient management in irrigated rice farms in the Red River Delta. Northern Vietnam. Selected paper for poster presentation at the international Association of Agricultural Economics (IAAE) Triennial conference, Foz de Iguacu, Brazil.

United Republic of Tanzania (2015/20162024/2025). Agricultural Sector Development Strategy-II. Retrieved from: extwprlegs1.fao.org/docs/pdf/tan 160643. pdf.

World Bank Group (2012). Tanzania Mainland Poverty Assessment. Retrieved from: https://www.worldbank.org/dam/africa/Ta nzania/Report/pdf. Accessed on July 23, 2020.

Yamano, T., Labarta, R., Arauna, A., Huelgas, Z (2016). Adoption and impacts of international rice research technologies. Retrieved from: https://www.rese arc hgate.net/ publication/293821102Adoption-and-impacts-of-international.

Yamazaki, S., Resosudarmo, B (2008). Does Seeding Farmers Back to School Have An impact? Revisiting the Issue. Dev. 46(2). 